\title{
Anti-democratic revolutionaries or democratic reformers? A review essay of Janek Wasserman's The Marginal Revolutionaries: How Austrian Economists Fought the War of Ideas
}

\author{
Stefan Kolev ${ }^{1,2}$
}

Accepted: 15 November 2020 / Published online: 14 December 2020

(C) The Author(s) 2020

\begin{abstract}
This paper provides a critical reading of Janek Wasserman's The Marginal Revolutionaries: How Austrian Economists Fought the War of Ideas. Wasserman depicts the evolution of the Austrian School from the 1860s until today, a particularly illuminating narrative for the readers of this journal. The breadth of portrayed economists, their cultural embeddedness in Austrian and US contexts, and the complexity of configurations across the school's generations create a rich and readable story. The last third of the book suffers from allegations about the ideological agenda and institutional power of the Austrian economists which sometimes lack sufficient substantiation. The paper indicates how both in their theorizing and in their political activities, the Austrian economists can be seen as reformers instead of revolutionaries, and as constitutionalists instead of anti-democrats. Despite these disagreements, Wasserman's portrayals evoke largely fair and challenging impulses both to scholars working in the Austrian research program and to those interested in the Austrian School's long history, regardless of one's ideological positions.
\end{abstract}

Keywords Austrian school $\cdot$ Central European history $\cdot$ Neoliberalism $\cdot$ Ideas and institutions $\cdot$ Role of economists

JEL classification $\mathrm{A} 11 \cdot \mathrm{B} 13 \cdot \mathrm{B} 25 \cdot \mathrm{B} 31 \cdot \mathrm{F} 53$

Stefan Kolev

stefan.kolev@fh-zwickau.de

1 Faculty of Business and Economics, University of Applied Sciences Zwickau, Kornmarkt 1, 08056 Zwickau, Germany

2 Wilhelm Röpke Institute, Erfurt, Germany 


\section{Yet another history of the Austrians? Yes, please!}

Janek Wasserman has published an important book, The Marginal Revolutionaries (Wasserman 2019), which is of special relevance for the readers of this journal. Wasserman provides a thought-provoking history of the evolution of the Austrian School, a narrative which spans over 150 years. Starting in the decades ahead of the publication of Carl Menger's Grundsätze der Volkswirthschaftslehre (Menger 1871), or Principles of Economics, the story ends with the most recent ramifications in the Austrian research program and today's relevance of the ideas commonly associated with this research program. Wasserman's endeavor is certainly a bold one, given the innumerable historiographic portrayals of this scholarly community which have been available for almost as long as the community has existed. The book may strike the readers of this journal as a civilized provocation. While certainly written from a critical perspective, Wasserman's style is much less characterized by the "hermeneutics of suspicion" (Boettke 2019) or the "malevolence assumption" (Kolev 2020), which have become so common in numerous recent books on this history of (neo-) liberal political economy. The book is an invitation to revisit the history of a scholarly tradition with a rather unique longevity, including episodes and protagonists that have been undeservedly forgotten. A number of myths, shared by both friends and foes of this research program, persist and deserve to be challenged.

Wasserman is a historian with profound knowledge of Central European history in general and of Vienna as a hotspot of Central European civilization in particular, as already discernible from his earlier book Black Vienna (Wasserman 2014). The Marginal Revolutionaries profits significantly from this expertise, as one can recognize from the substantive, ideological, and lingual breadth of sources he has harnessed. Equally important is Wasserman's multifaceted approach at what he aims to depict. His narrative about the Austrian School (AS) is about "a family biography; a history of economic thought; a sociology of knowledge; a transnational, political theory; and a history of political ideologies" (Wasserman 2019, p. 5). From the very beginning, he is wary of the usage of the "school" notion, which is often utilized in an inflationary manner, and struggles throughout the book to show carefully the extent to which the notion is applicable to the Austrians. His answer differs from period to period, and allows for the existence of different school-like configurations over time.

In these efforts to demarcate the borders of the school, Wasserman consistently reminds the reader that the historiography of this scholarly community, especially when conducted by the Austrians themselves, has suffered from two key types of narrowness, which this review calls a personal and a temporal one. Regarding the personal narrowness, Wasserman's narrative shows how many other intriguing figures than the "giants" like Menger, Böhm-Bawerk, Mises or Hayek played non-negligible roles in the evolution of the AS. Regarding the temporal narrowness, he correctly identifies another deficiency in the ways some of today's Austrians think of their history. The reviewer shares Wasserman's observation that "figures before Mises and Hayek are known but primarily serve a symbolic rather than substantive purpose in current research" (Wasserman 2019, p. 7), whereby the decades before the 1920s are often demoted to a pre-history of what really kicked off with the socialist calculation debates. Let us explore, in a chronological manner, the more and the less successful aspects of 
the attempt to overcome these two types of narrowness - which is a daunting task, given the constraint to cover more than 150 years on less than 400 pages.

\section{The early years and the golden pre-1914 age}

Wasserman's story of Menger's Principles of Economics differs from some of the conventional wisdom about Menger's role in initiating the AS. The reader is reminded that Principles was very soon out of print, and that this remained so all the way until the second edition was posthumously published by his son Karl in 1923. While many aspiring minds in the successive AS generations received decisive inspirations from reading Principles, its general impact in the German-speaking academy may be overstated in the canonical accounts. In addition, Wasserman critically addresses the question whether the marginal revolution was a revolution at all. It certainly challenged classical political economy as practiced in England, but the notion of subjective value theory had by the time a long-standing history (not only, but also) in German-language economics. In that regard, Menger's book was perhaps intended to be a reformist, rather than a revolutionary, contribution. Menger's dedication of Principles to Wilhelm Roscher, the head of the Older German Historical School, has often been interpreted as such a reformist, non-revolutionary signal (Streissler 1990), although it is of course possible that also career-strategic reasons on the part of young Menger contributed to its deferential dedication.

The tone became much less deferential very soon in his Untersuchungen über die Methode der Socialwissenschaften, und der Politischen Oekonomie insbesondere (Menger 1883), or Investigations into the Method of the Social Sciences with Special Reference to Economics, and initiated the famous Methodenstreit. Although, again, explicitly aimed at a reform of German political economy, Wasserman traces the radical change of Menger's rhetoric vis-à-vis his German counterparts to the "silence" that was "deafening" in what Wasserman assesses as lukewarm reviews of his Principles in German-language journals (Wasserman 2019, p. 31) - including a rather dismissive one by Gustav Schmoller (1873 [2004]) who was among the rising stars of what was later called the Younger Historical School. Whether the reception of the book was indeed lukewarm and "not encouraging," as also judged by Hayek (1934, p. 403), has recently been challenged in an updated overview of the reviews - their number, the prominence of the reviewers, and of the outlets can actually be seen as quite significant for a scholar's first major publication (Schumacher and Scheall 2020, p. 170, p. 181). Perhaps the conflict into which Menger and Schmoller stumbled during the 1880s was also a signal of emancipation among the tensions between the new German Reich and Austria-Hungary over political and cultural dominance in Central Europe, and this conflict was certainly formative for the emergence of both school-like formations, which increasingly gravitated around Berlin and Vienna. Wasserman provides a colorful portrayal of the larger and smaller battles that ensued (Wasserman 2019, pp. 31-37), and shows that the often-repeated textbook version of how the debate was primarily over the relevance of deduction and induction is way too narrow. Rather, a quest for conceptual clarity about the different sub-disciplines within economics, and especially a debate over the issues of normativity and the related questions of the admissible role of the economist in shaping practical economic policy were already 
clearly discernible in the Methodenstreit (Horn and Kolev 2020). Precisely these quests - what economics is about, and what economists should do - would persist to occupy (and plague) German social scientists not only in the Werturteilsstreit in the 1900s and 1910s over value judgments, but also in the heated battles between Popperian critical rationalists and the representatives of the Frankfurt School in the 1960s that became famous as the Positivismusstreit.

As important as his writings was Menger's capability to attract younger minds. He did so in his Privatseminar initiated during the 1870 s, a format that would become a trademark of the AS. Wasserman invests a significant amount of energy into the portrayals of those whom Menger attracted into his orbit and who, as correctly assessed by Wasserman, were just as formative for the consolidation of the incipient school during the Methodenstreit. While he first introduces Eugen von Böhm-Bawerk and Friedrich von Wieser, the "usual suspects" within the second generation, he paints a far broader and more varied set of characters. The essential embeddedness of the early Austrians in the German discourses is emphasized by Menger sending his graduate students to Germany to spend time while writing their habilitations with the heads of the Older German Historical School: Wilhelm Roscher at Leipzig, Bruno Hildebrand at Jena and, above all, Karl Knies at Heidelberg. Upon the appointment to their professorships at Innsbruck (Böhm-Bawerk) and Prague (Wieser), the two are depicted as the true erectors of the school. Their activities within German-language academia in the still glowing Methodenstreit, their publications in the very early Anglo-Saxon journals (e.g. Böhm-Bawerk 1891; Wieser 1891), the English translations of their early books (Böhm-Bawerk 1890; Wieser 1893) and their networking efforts were crucial for the forging of an entity increasingly seen as a coherent group with a coherent research program. The Menger-Böhm-Bawerk-Wieser "triumvirate" attracted a number of further affiliates, most of them forgotten today despite contributions which the "triumviri" assessed as seminal: Emil Sax, Robert Meyer, Gustav Gross, Robert Zuckerkandl, Johann von Komorzynski, Hermann von Schullern zu Schrattenhofen, Viktor Mataja, Eugen von Philippovich, Rudolf Auspitz, and Richard Lieben. Some of them are depicted as belonging to the Austrian core, whereas others serve as connectors to other research programs: Philippovich with the Historical School, and Auspitz and Lieben to the mathematical economics of Léon Walras and others. Wasserman provides a differentiated picture of the sub-groups that had already emerged in those early days, and distinguishes - in line with the historiography as produced later by the AS itself between a Böhm-Bawerkian and a Wieserian branch (Wasserman 2019, pp. 39-51). Early on, the history of the AS can be captured in the metaphor of constant reformism: Every generation was respectful vis-à-vis the earlier contributions, but did not shy away from challenging tenets in "the received wisdom," thus producing a sequence of reforms - in the theoretical apparatus, the set of methods, and the areas of application.

From this point onwards, the book is visibly not only (and not primarily) about the history of economic analysis. While Wasserman's synopses of the economic theory of a thinker sometimes remain sketchy and vague, he spends considerable energy to identify the ideational load as well the institutional imprint the thinker left behind. Although his depictions are intriguing and captivating, every now and then they "leak in" the author's own ideological priors. Wieser, into whose portrayal Wasserman invests substantial energies throughout the first half of the book, provides an example. It is true that Wieser's Natural Value (Wieser 1893) can be seen as an avant la lettre 
contribution to the socialist calculation debates (Wasserman 2019, pp. 47-48) that are usually dated to begin only in 1920, but it is questionable that this book - and Wieser's scholarship in general - can be read in the dichotomous way proposed by Wasserman: "Wieser saw the world divided in two camps: either you were an individualist or a collectivist, both methodologically and ideologically. Wieser and the Austrians could only countenance the former" (2019, p. 43). Wieser's pervasive eclecticism has been both condemned and praised (Streissler 1999; Kolev 2019a), but the mélange of methodological and ideological tenets is crucial for understanding his approach. For good or bad, Wieser's work is anything but dichotomous.

Despite the AS's methodological breadth (e.g. regarding the usage of mathematics) and heterogeneity in the ideational sets (e.g. regarding the willingness to break with certain tenets of earlier nineteenth-century liberalism), Wasserman provides a convincing account of how their own professionalization succeeded through founding the Gesellschaft österreichischer Volkswirthe (Association of Austrian Economists, GÖV) as well as the Zeitschrift für Volkswirtschaft, Socialpolitik und Verwaltung as antidotes to the German Verein für Socialpolitik and the Schmoller-edited Jahrbuch für Gesetzgebung, Verwaltung und Volkswirtschaft im Deutschen Reich - without discontinuing their participation at the Verein's meetings and keeping up their publications in the Berlin Jahrbuch. In addition to these academic institutions, the reader learns a lot about the broader institutional imprint of the early generations. Wasserman calls the predominant political attitude "paternalistic progressivism": While not on the conservative side, the Austrians were also not egalitarian democrats, retaining instead an elitist view of their own role vis-à-vis their fellow citizens. Many of the early Austrians spent large parts of their career as officials of their Empire in decline, a prominent example being the multiple tenures of Böhm-Bawerk and Wieser as imperial ministers. Politically, both in their newspaper pronouncements and explicit activities as officials, Wasserman correctly identifies that "the early Austrians were no radicals" (Wasserman 2019, p. 53). Rather, the early Austrians showed a much more pronounced inclination towards reforms - be it of theory, method or the polity - than towards revolutions.

Wasserman joins Hayek in calling the decade prior to 1914 "the golden age" of the AS, both regarding its internal evolution and its international reputation. Deeply embedded in the networks of Viennese circles of the most diverse orientations and concerned with much more than "just" economics, Wasserman depicts the cross-fertilizing discourses in a city in whose celebrated cafés one could encounter "students of civilization" (Dekker 2016) as diverse as Sigmund Freud, Josip Broz Tito, Joseph Stalin or Gustav Klimt. Throughout the book, Wasserman emphasizes the Austrians' struggle for power in their roles as academics, intellectuals, and bureaucrats. This notion of near-omnipotence strikes at times as somewhat exaggerated. Especially in the academic domain, it is worth remembering that the AS was not overly successful in occupying the professorships in Austria-Hungary and was almost irrelevant in Germany. Regarding the Austrians' home university landscape, Karsten von Blumenthal's careful study discloses that barely half of the economics chairs were occupied by AS-related scholars (Blumenthal 2007, pp. 6675). Within the battles with the Austro-Marxists, Wasserman introduces the SchumpeterMises generation, including broadly, as is always the case with generational demarcations, Richard Schüller, Richard Reisch, Franz Xaver Weiss, Alfred Amonn, and Richard von Strigl. This cohort of scholars transitioned from being young scholars to mid-career 
scholars during the "golden age" and continued the earlier battles, be it against the historicists or the socialists, but also had fights among themselves, over substance as well as professional positions.

The treatment of Schumpeter is particularly noteworthy for today's Austrians. A lot of energy has been invested in recent decades to "excommunicate" Schumpeter from the AS, and of course he - very much in line with his understanding of innovation as the combination of previously unconnected inputs - combined many other, "nonAustrian" strands of inspiration like Walrasian equilibrium theory, Marxian dynamics of capitalism and Weberian socio-economics. Yet, Wasserman is very convincing in delineating how the early Schumpeter, in particular, cannot be understood without his fundamental contributions to the AS, and how the AS of this and the next generation cannot be understood without Schumpeter. The roots of the decades-long competition between Schumpeter and Mises, one of the reasons why later Misesian Austrians have been keen to ban Schumpeter from the AS discourses, is aptly portrayed, as are the different reasons for their different professional success, including the prevalent antiSemitism in fin-de-siècle Vienna (Klausinger 2014). Finally, despite all this competition within the school and all the battles with other communities, the gold in the "golden age" had very much to do with its politico-economic stability - an asset which the Austrian reformers appreciated highly in their attempts to bring the pre-1914 order closer to their notions of liberalism, in stark contrast to the revolutionary waves of thought and action, which destroyed not only their beloved Empire, but also any sense of stability in the three decades after the end of World War I.

\section{The interwar "years of high theory" and the end of the First Republic}

The demise of Austria-Hungary certainly was a fundamental break for the AS and its protagonists. They lost a number of universities outside the First Republic, where appointments had been common before World War I, the financial attractivity of academic positions deteriorated, and Vienna did not need as many bureaucrats as it did when it governed one of the largest European states. The "triumviri" left the scene Menger died in 1921 but had long retreated from the public since his retirement in 1903, Böhm-Bawerk passed away in 1914, as well as his brother-in-law Wieser in 1926. Several of the economists lost their "von" and related nobility titles like "Ritter" ("knight," in the case of Böhm-Bawerk) or "Freiherr" ("baron," in the case of Wieser), as the First Republic was keen to start with egalitarian credentials. While this loss was certainly an issue for some of the Austrians, it was perhaps not in line with Wasserman's story of the Austrians' elitism to mention not only, as he does on page 19, that the Mengers' father had been ennobled with the title "von Wolfensgrün" (not "von Wolfensgrünen" as in Wasserman), but also to mention that in the 1860s Menger and his brothers Anton and Max decided to drop the nobility title, in the interpretation of Carl's son Karl, due to the fact that Menger brothers' self-understanding as democrats clashed with belonging to the nobility (Yagi 2011, p. 5; Schumacher and Scheall 2020, p. 165). Equally, Wasserman mentions that Menger tutored Crown Prince Rudolf and emphasizes the power aspect of how the "appointment reinforced his insider status and permitted him greater political influence" (Wasserman 2019, p. 26), but misses to mention that Carl and his tutee co-authored a pamphlet against the Austrian nobility 
(Schumacher and Scheall 2018, p. 658). Another detail, which Wasserman spares the reader not familiar with the structure of Austrian nobility, is that all the "von-s" in the ranks of the AS belonged to the lower levels of nobility Edler, Ritter or Freiherr (Streissler 1969, 257-258), a fact that has to be taken into account before too quickly attributing to these titles too much of an aura of power and status.

Amid this picture of fundamental transformations in the emergence of the First Republic, Wasserman depicts a series of important transitions in the profiles and selfunderstanding of the Austrians: 1) their increasing preoccupation with becoming public intellectuals; 2) their primarily extramural discourses due to unfortunate successions at the University of Vienna and the related exhaustion of the intramural discourses within the university; and 3) their increasing integration in international networks, foundations, and organizations. Still, there were continuities, especially in the intellectual fronts. The battles with socialists and social democrats, prior to 1914 primarily of academic nature, lost their abstractness with the possibilities of a Bolshevik victory in the Russian civil war. Mises' lecture on socialist calculation in January 1920 in front of the newly founded Nationalökonomische Gesellschaft (Austrian Economic Association, NOeG), an institution of curious fate almost missing in Wasserman's story (Klausinger 2015a), re-connected to debates which had started much earlier in the nineteenth century and had occupied large parts of the pre-1914 seminars in the exchange between the AS and the Austro-Marxists.

The scene of (more or less private) seminars and Kreise flourished in the 1920s. A competitor to Mises' famous Privatseminar was the Spann Kreis around Othmar Spann, but also the group which formed around Wieser's chair successor, Hans Mayer. And while the fourth generation, some of whom fought in the Great War as teenagers at the front, had to be very careful in their choices of belonging to those groups set up by the third generation, they also initiated their own circles like the Geist-Kreis around Hayek. Wasserman draws a set of rich portrayals of protagonists of this fourth AS generation, some of whom - like Schumpeter in the third generation - have been "purified" out of the AS in recent decades: Oskar Morgenstern, Fritz Machlup, Helene Lieser, Gottfried Haberler, and Herbert Fürth, but also important contributors to philosophy or neighboring social sciences like Erich Voegelin, Felix Kaufmann, and Alfred Schütz. Wasserman shows their coexistences in alternating modes of cooperation and competition, of a sense of belonging together and yet of struggling for the scarce academic or near-academic positions, including the Institut für Konjunkturforschung founded in 1927 that helped business cycle research become one of the AS trademarks (Klausinger 2006, pp. 26-37). A look at the monthly reports of the Institut (Wasserman 2019, pp. 127-129) provides a nuanced picture of whether the Austrians "predicted" the Depression.

In the course of the 1920s, and especially with the advent of the Depression, a new ideational front opened up from the right. Apart from the Catholic conservatism of the Christian socialists and along with the German nationalists, fascism entered the scene after its advent in Italy. Wasserman draws a rich and gloomy picture of how the Viennese civilization, sometimes compared to Florence of the Renaissance (Hennecke 2000, pp. 25-27), was gradually devoured by the varieties of fascism native in Austria, coming from Italy, and soon also from Germany. Wasserman joins the narrative, albeit in a more differentiated version, of the alleged proximity of the Austrians to fascist ideologies. The often-quoted passage by Mises in his Liberalism about the preferability of fascist 
economic policy over the Bolshevik alternative (Mises 1927 [2005], pp. 29-30) leads Wasserman to state (Wasserman 2019, p. 134) that "[w] hile Mises was no fascist himself," he "was even willing to countenance the fascist critique of democracy." As most authors who quote the passage about fascism having halted communism's advent and deserving merit for that, Wasserman fails to quote the end of Mises' paragraph: 'But though its policy has brought salvation for the moment, it is not of the kind which could promise continued success. Fascism was an emergency makeshift. To view it as something more would be a fatal error" (Mises 1927 [2005], p. 30). What Mises explicitly aimed at is a constitutionally constrained democracy that not only protected economic institutions such as property rights, but also political institutions such as the rights of minorities. To conflate his plea for non-interventionism with an anti-democratic attitude is misleading. Similar to his ordoliberal contemporaries, Mises feared that an increasing degree of discretionary interventions would make democracy increasingly attractive for special interests to capture democratic decisions-making (Eucken 1932 [2017]; Rüstow 1932). And while the Austrians were indeed not in favor of an unrestrained democracy, this does not imply that they were anti-democrats - actually, their position may imply the very opposite. It is essential to distinguish between the principle of democracy and its concrete forms (Vanberg 2011), and while one can be an ardent supporter of the principle of democracy, that does not mean that one must unconditionally support the concrete form in one's time - it could actually mean that scholars have the duty to look out for better, more sustainable forms. The full-fledged post-1919 Austrian democracy and its constitution shaped substantially by Mises' classmate and life-long friend, Hans Kelsen (Olechowski 2020, pp. 271-306), proved to be a very fragile artefact. Mises' reformist efforts in the 1920s and 1930s were based on fear of the revolutionary potential a democracy could unleash when its constitutional provisions are weak - and this fear proved prescient, given Hitler's democratic election and the easy destruction of the Weimar constitutional order that plunged Europe into its darkest hours.

The period from 1926 to 1939 has been aptly called "the years of high theory" (Shackle 1967), and the Austrians were among the key players in the series of debates which were waged. The story of the emergence and impact of the AS's position on business cycle theory and policy is unfortunately conflated by Wasserman with the structural transformations of the age. The notion of austerity used in this chapter implicitly connects the debates of the Great Depression to the austerity debates of the post-2007 Great Recession, which proves too much of a stretch. In addition, the cryptonormativity that often accompanies "austerity" when employed in policy debates or when historicized to blame policies which the author dislikes, as for example in the prominent case of Blyth (2013), also surfaces in Wasserman's discussion. First, it does not become clear whether the "austerity measures, arranged by the conservative Christian Social government and American investment bankers" (Wasserman 2019, p. 108) are caused by cyclical measures based on the AS's business cycle theory, or by structural necessities of shrinking the severely oversized imperial bureaucratic apparatus. After all, the "rump state" of the First Republic had a population of about 6.5 million, 2 million of them in Vienna, compared to Austria-Hungary's over 50 million at the outbreak of World War I. Wasserman indeed mentions the structural problem of the young "rump state" with "hydrocephalic Vienna" (Wasserman 2019, p. 108), but not as a cause of the "austerity measures." Also, the post-2007 Great Recession's worries of austerity take place in very different monetary conditions when compared to the 
debates about the Great Depression. While Wasserman rightly calls the Austrian inflation in the 1920s "rampant" (Wasserman 2019, p. 108), it may be worth mentioning that it actually was a hyperinflation, which in the course of few years let prices explode by the magnitude of five-digit per cent rates, a process whose unfolding caused very serious social costs (Wicker 1986, pp. 354-356). In addition, the hyperinflationinduced devaluation of savings hit badly normal citizens who had already suffered the devaluation of their war-related government bonds, incurring extreme political costs for the legitimacy of the fragile Central European democracies (Hill et al. 1977, pp. 307310). Thus, "austerity measures" against such a set of problems appear hardly comparable to the aims and means discussed in the austerity debates of today.

The history of the Viennese Institut für Konjunkturforschung, and the Great Depression more generally, initiates Wasserman's narrative of the internationalization of the Austrians, focusing on the prominent role of the Rockefeller Foundation in the Institut's founding and in numerous further projects and endeavors of the Austrians in the decade of their successive emigration from Vienna, a process accompanied by the post-1934 waves of extremism which shattered the First Republic. As with the chapters on the "golden age," the sections on the 1930s do not limit themselves to the "usual suspects" like Hayek, but instead depict the colorful fourth generation with its heterogeneity, including among others the stories of Machlup, Morgenstern, Haberler, and Fürth. They differed, among other things, regarding: 1) their trust in laissez-faire as the adequate policy approach to the Great Depression, with Haberler as the one with the lowest trust in automatic, purifying correction processes, 2) the mathematization of economics, with Morgenstern as the most enthusiastic, and 3) their relative appreciation of the key figures in the third generation, most notably Schumpeter and Mises. Regarding the policy responses to the Great Depression, as a complement to Wasserman's story, a reminder is necessary that the recommendations, which the fourth generation pronounced as public intellectuals in the media, were more pragmatic in substance and more moderate in rhetoric than the textbook version of what the Austrian business cycle theory recommends (Klausinger 2005). Wasserman captures well their sense of belonging together, and yet at the same time the spirit of a constant competition among them - a climate of what may be called "coopetition" characterized the interactions within this generation for decades (2019, pp. 152-160). All of them and most of their friends left Vienna in the course of the 1930s, with mixed trajectories of emigration and finding jobs in Anglo-Saxon academia. In that process of leaving Vienna and resettling to a culturally alien academic and social world, the Austrians also fought new wars during the 1930s, most prominently the Hayek-Keynes controversy, the dispute over capital theory with Frank Knight, the debates at the Colloque Walter Lippmann, and the second round of the socialist calculation debate with the market socialists. While the depiction of the theoretical core of those debates is sometimes vague and too concise, Wasserman does succeed in depicting the sociological configurations and dynamics of the AS.

\section{The battle for Western civilization and the postwar decades of the émigrés}

By the late 1930s, Vienna had become a desolate place. Even though Wasserman is imprecise in claiming that Hans Mayer had joined the Nazi party - in footnote 6 on 
page 165 , he cites Klausinger (2015b) where such a claim is not contained - the Viennese remnants of the school around Mayer were a shadow of the old days after the Anschluss in 1938 at the latest, including collaboration with the new regime imposed by the Germans. As to the émigrés, chapter 5 joins the usual narrative that in the 1940s the Austrians "turn away from economics" as visible especially in The Road to Serfdom (Hayek 1944) and Capitalism, Socialism and Democracy (Schumpeter 1942). This may have been true by the standards of the places where these books were written: Hayek spent large parts of the war at Cambridge, UK due the LSE's evacuation, while Schumpeter was at Cambridge, MA since his joining of Harvard's faculty in 1932. And while it is plausible that from Morgenstern's Princeton even The Pure Theory of Capital did not qualify as modern economics (Wasserman 2019, p. 163), the claim that the Austrians "turn away from economics" is surprising in one regard; Wasserman's own history of the evolution of Austrian economics easily renders another interpretation. While it is true that the shift from The Pure Theory of Capital (Hayek 1941) to The Road to Serfdom (Hayek 1944) or from Business Cycles (Schumpeter 1939) to Capitalism, Socialism and Democracy (Schumpeter 1942) is a turn away from an analysis of the market process, the analysis of politico-economic institutional frameworks which is at the core of both books is an integral part of Austrian economics as depicted by Wasserman, especially in the Wieserian tradition - and both Schumpeter and Hayek had an early affinity to this branch of the school. Thus, in the very self-understanding of the Austrians, the transformation in the 1940s is interpretable as being within economics, not away from economics (Boettke 2018, pp. 229-239).

While the summary of Capitalism, Socialism and Democracy captures well the subtle defense of capitalism and bourgeois civilization, the summary of The Road to Serfdom is different, both in tone and in substance. It contains several contradictions like Hayek's alleged defense of “'laissez-faire' economics” (Wasserman 2019, p. 183), despite several passages in the book that explicitly reject laissez-faire, or Hayek's purported aim "to win converts from the socialist camp" by softening the book through his focus on institutional frameworks - without providing any proof of that intention; the dedication of The Road to Serfdom can well be interpreted in the opposite way. From the Schumpeter-Hayek comparison, the reader can already discern two central characteristics of the last third of the book which distinguish it - as seen from the reviewer, in a regrettable way - from the first two thirds, pushing the final 100 pages into the proximity of the neoliberalism literature. First, the allegations of an ideological agenda, which in the earlier sections were limited to more or less abstract accusations of elitism and anti-democratic sentiments, become palpably sharper; and second, different protagonists are confronted with these allegations to very different extents, Hayek clearly being Wasserman's favorite target.

Despite this weakness, the final chapters also contain noteworthy and illuminating passages, not so much regarding the "usual suspects" Mises and Hayek, but rather the less prominent Austrians Machlup, Morgenstern, and Haberler. The diversity of their strategies in Anglo-Saxon academia is captured well, and manages to stay away from the stereotypical accusations in many histories of the AS as conducted by Austrians who claim that they did little more than simple "mimicry" vis-à-vis the trends of "modern," postwar economics. The most notable example is the convincing picture of Morgenstern's contributions to game theory as being intended to deepen the insights 
of the AS's marginalist tradition (Wasserman 2019, pp. 187-194). The depiction of the Mont Pèlerin Society (MPS) suffers from some imprecisions (Alexander Rüstow did not attend the first meeting in April 1947, unlike stated on page 196, while Walter Eucken did, but is omitted here; Ludwig Erhard became minister of the economy, not minister of finance, unlike stated on page 203) and is structured around allegations of Hayek's ideological agenda. Wasserman claims that the strategy behind the MPS was to keep away "moderate liberals like Viner who declined participation" (Wasserman 2019, p. 197) even though, as archival research of the reviewer in the Jacob Viner Papers at Princeton shows, the Hayek-Viner correspondence on the MPS is from June 3, 1947 (Hayek) and June 9, 1947 (Viner). This is before any clear agenda of the MPS had emerged, let alone had become communicable. The following sentences (2019, pp. 198-199) capture the ambiguities and implicit allegations of Wasserman's narrative of Hayek's postwar endeavors: "They felt obligated to defend the order that had produced the wealth and prosperity from which they had benefited so richly. This elitism informed their defense of so-called universal civilizational values. As the preamble of the MPS evinces, their interventions, despite professed objectivity and scientific neutrality, had ideological impacts that reinforced conservative values."

Without providing evidence, Wasserman simply neither allows for the Austrians to be defenders of an order which produces wealth and prosperity for everybody, nor does he make clear why the values they defend were not universal, nor in what sense the values behind their interventions were conservative. Equally, the summary of The Constitution of Liberty (Hayek 1960) contains - in passing and without any evidence - the claim that Hayek "begrudgingly" proposed provision of social security measures, or that his proposals aimed at "rolling back health, unemployment, and disability insurance to a "uniform minimum"' (Wasserman 2019, p. 209) - even though The Constitution of Liberty is dedicated "To the unknown civilization that is growing in America" where many of Hayek's proposals by no means imply a roll-back of the welfare state, quite on the contrary.

Passages like this are unfortunately coupled with Wasserman's power narrative of the postwar decades. While the ambitions of the Austrians to be part of the political discourse and to shape it both by personal interventions as public intellectuals as well as by institutional innovations like the Viennese economics societies GÖV and NOeG, the Zeitschrift or the Institut are a central part of the earlier sections of the book, in the last third of the book they become dominant to an extent which at several intersections appears exaggerated. The main problem of the power narrative is its lack of context. While the portrayals of Haberler as an influential figure in the evolution of GATT as a central institution for postwar world trade (2019, pp. 223-227), and of Machlup as an influential figure in the debates about international monetary economics and exchange rate regimes in the Bellagio Group (2019, pp. 228-231) are rich and illuminating, Wasserman omits something crucial. The Keynesian consensus heavily dominated not only postwar economics in the US, but also the fundamental pillars of the postwar economic order, such as the IMF and the World Bank. If only the impact of MIT as the leading economics department (Weintraub 2014) was introduced to the picture, the near-omnipotent Austrian "masters of the universe" from Wasserman's narrative would appear in rather different light. In addition to the Keynesian domination, the importance of Marxian economics in crucial fields like development economics (Perraton 2007) relativizes even more the impact that the Austrians could have. 
To sum up, the relative power of individuals, interests, and ideas in the postwar years require a more careful disentangling than the AS-focused story which Wasserman provides. To impute the making of the postwar order on single scholars without embedding them into the larger picture of their ideational competitors, and to attribute the transformation of this order to intellectual debates only - without a clear statement whether the Bretton Woods system was a viable arrangement in light of economic policy on both sides of the Atlantic in the 1960s - lacks decisive context. In addition, such an approach may also be too much in line with the Austrians' belief that ideas matter, while material conditions and special interests are missing from the power narrative.

\section{Recent decades and debates in the US and beyond}

The story of the Americanization of the AS captures well the tensions between the ageing émigrés and the young US Austrians. Luckily the portrayal of the heterogeneity in the US transcends the stereotypical division of Misesians vs. Hayekians. In telling the story of a Misesian émigré like Emil Kauder (Wasserman 2019, pp. 240-243), which Wasserman has conducted in more detail in this journal (Wasserman 2020), he employs the intriguing categories of Machlup to structure the field: "Austrians," "unAustrian Austrians," and "non-Austrian Austrians" (Machlup 1982). While the first were Austrian by birth and socialization and belonged to the AS, the second were Austrian by birth and socialization but combined AS insights with other inspirations, while the third were born and socialized mostly in the US and continued to develop the AS insights. The Austrian revival post-1974 is embedded in the larger picture of how "Austrians" and "non-Austrian Austrians" co-existed, including the special role of NYU around Israel Kirzner becoming the intellectual home of Ludwig Lachmann, Fritz Machlup, and Oskar Morgenstern in the final stage of their careers (Wasserman 2019, pp. 246-252). Wasserman reconstructs how the competitive spirit of the 1920s and 1930s flared up one last time in the fourth generation once Hayek received the Nobel Prize in 1974 (Morgenstern's mentee Martin Shubik never received a Nobel, unlike stated on page 251). After the Nobel, Hayek is portrayed to have become "the representative figure" of the AS (he taught at Freiburg until 1969, not 1968, and came back to Freiburg in 1977, not 1976, unlike stated on page 259; Walter Eucken Institute 2020). The story of the think-tanks like the Institute of Economic Affairs in the UK or the Cato Institute in the US, and of the private donors associated to the AS, does not differ from the standard narrative. Unfortunately, also the Pinochet narrative does not differ from the stereotypical way it is told. Wasserman claims that "Pinochet invited Hayek to Chile" (Wasserman 2019, p. 262), disregarding the ample recent evidence in a paper (Caldwell and Montes 2015) he cites in footnote 48 that such an invitation was never extended by the dictator.

In the final chapter of the book, Wasserman produces a picture of the most recent developments in the AS. The rhetoric of this chapter embodies best the spirit of the last third of the book. Lines like "a coterie of devoted scholars keeps these outlets alive and vibrant" (Wasserman 2019, p. 276) regarding the contributors to this journal are rather distinct from the rhetoric of the early parts of the book. His overall skepticism about the US Austrians as ideological simplifiers is most pronounced in this chapter, while the 
original contributions of the most recent generations to the AS research program are at best sketched. The divisions along the lines of George Mason University versus Ludwig von Mises Institute are intriguing to read, but suffer from one central deficiency. Wasserman seems to have avoided conversations with LvMI representatives, while conversations with GMU protagonists are palpable from the text. While Wasserman produces a narrative which is in line with the reviewer's assessment about the highly detrimental effects of the alignment of the Rothbardian AS strand with the "Alt-Right," the portrayal of this entanglement would have profited from the alternative perspective of LvMI protagonists. A similar asymmetry emerges in the portrayal of the European divisions between the Hayek Institute in Vienna and the Hayek Society in Berlin versus the NOUS Network in Freiburg. For full disclosure, this reviewer is a founding member of NOUS, and as such shares Wasserman's account about the extremely damaging contamination of institutions named after Hayek with the Austrian and German farright (Kolev 2019b), but the other side remains regrettably voiceless. If an objective history of such recent events is possible at all, collecting all perspectives is indispensable.

\section{Conclusion: Anti-democratic revolutionaries or democratic reformers?}

"By exploring this multifaceted collective, we gain a greater understanding of the issues that face the contemporary world and how we might respond to the problems that the Austrians helped diagnose - and create" is Wasserman's closing sentence. His book is indeed helpful to gain a more nuanced understanding of the multifaceted history of the AS, and has to be applauded for the bold attempt to cover such a long timeline and such different cultural contexts in the limited space of a single book. As outlined in this review, the book has numerous strengths, perhaps first of all, its great readability. In terms of the different periods covered in the book, the decades ahead of 1950 will provide the reader with the genuine intellectual enrichment, while the history of the recent evolution of the school is often tainted with crypto-normative allegations about the hidden agenda of powerful "masters of the universe."

The notion of revolutionaries has been challenged at several places above, both regarding the theoretical and the political hopes of the Austrians. Despite the aspirations of every scientist to contribute something genuinely innovative to his discipline, neither Menger vis-à-vis the German-language mainstream of his days nor his followers must be interpreted as having deployed a revolutionary agenda in economics. Instead, the success and the unique longevity of the AS is attributable to a sequence of generations who innovated within the already existing research program and reformed this program by adding marginal contributions to it - of course, the significance of these contributions differed. If marginalism is understood as a consistent worldview on economy and society, this reformist and gradualist spirit can actually be identified as the very core of such a marginalist Weltanschauung. In this vein, one of the major strengths of Wasserman's book is precisely to illuminate the diversity of scholars who can be associated with the school, as well as the plurality of the dimensions along which they added their scholarly marginal contributions. Politically, their liberalism and the recurrent suggestions of better institutional frameworks is very much interpretable in terms 
of Popperian piecemeal engineering. In contrast, the revolutions of their time were seen by the AS as the great tragedies of the twentieth century; there are good reasons to question whether what has been called "the Reagan-Thatcher revolution" really meant the revolutionary swerve it is often portrayed to have brought about, especially if one soberly revisits the various indicators of the fiscal size of government, scope of the welfare state, etc. over the past 40 years. The power imputed to the Austrians in effectively shaping institutional frameworks, especially in the postwar context, appears at times as quite exaggerated, especially given the missing context of the Keynesian mainstream of the time and the disregard of the politico-economic transformations which cannot always be singularly attributed to ideas, Austrian or other.

Regarding the allegation of an elitist anti-democratic approach to politics, this book is fairer than many other narratives in the literature about the (neo)liberal evil-doers. While it is true that in Austria many AS representatives were culturally raised in the spirit of their country's elite, that some made it into the political elite of their Empire, and that some succeeded in integrating into the scholarly elite of Anglo-Saxon academia, Wasserman is sometimes too quick to draw the connection between such elitist lifeworlds and an antipathy to democracy. As outlined above, the Austrians can be portrayed as constitutionalists who supported the principle of democracy and simultaneously searched for more sustainable forms than those which so tragically failed during the 1920s and 1930s. Taking seriously the vulnerability of democratic decision-making from usurpation through the lobbyists of special interests can be seen as the opposite of being an anti-democrat. As to the "checks and balances" of constitutionalism, our age of aspiring autocrats in the US and Eastern Europe may well teach us that constraints on otherwise unrestrained power, which were institutionalized by a sequence of constitutionalists over the past 250 years, are among the quintessential hopes of democrats that democracy will survive the autocrats - not despite the constraints, but because of them.

Despite these critiques and the minor factual imprecisions, the book is written by a genuine expert of Central European history, whose cultural sensitivity vis-à-vis the Austrians - in their diversity, instead of focusing on the "usual suspects" - is the great asset of the book. The change in rhetoric in the last third reads as though Wasserman's empathy is directed at protecting the cultural complexity of the early Austrians from the distortions which the Americanization of the AS entailed, a stance with which the reviewer sympathizes to a large extent. Even more important for our times is another asset. When compared to the vitriol that shapes large parts of the recent neoliberalism literature, even the last third of the book clearly testifies that it was written by a moderate who, above all, reconstructs the fragility of our civilization from the $1860 \mathrm{~s}$ until today.

Funding Open Access funding enabled and organized by Projekt DEAL.

Open Access This article is licensed under a Creative Commons Attribution 4.0 International License, which permits use, sharing, adaptation, distribution and reproduction in any medium or format, as long as you give appropriate credit to the original author(s) and the source, provide a link to the Creative Commons licence, and indicate if changes were made. The images or other third party material in this article are included in the article's Creative Commons licence, unless indicated otherwise in a credit line to the material. If material is not included in the article's Creative Commons licence and your intended use is not permitted by statutory 
regulation or exceeds the permitted use, you will need to obtain permission directly from the copyright holder. To view a copy of this licence, visit http://creativecommons.org/licenses/by/4.0/.

\section{References}

Blumenthal, K. v. (2007). Die Steuertheorien der Austrian economics: Von Menger zu Mises. Marburg: Metropolis.

Blyth, M. (2013). Austerity: The history of a dangerous idea. New York: Oxford University Press.

Böhm-Bawerk, E. v. (1890). Capital and interest: A critical history of economic theory. London: Macmillan.

Böhm-Bawerk, E. v. (1891). The Austrian economists. Annals of the American Academy of Political and Social Science, 1(3), 361-384.

Boettke, P. J. (2018). F. A. Hayek: Economics, political economy and social philosophy. London: Palgrave Macmillan.

Boettke, P. J. (2019). What happens when the economic past is left to the kindness of its enemies? The Independent Review: A Journal of Political Economy, 24(2), 279-287.

Caldwell, B., \& Montes, L. (2015). Friedrich Hayek and his visits to Chile. The Review of Austrian Economics, 28(3), 261-309.

Dekker, E. (2016). The Viennese students of civilization: The meaning and context of Austrian economics reconsidered. New York: Cambridge University Press.

Eucken, W. (1932 [2017]). Structural transformations of the state and the crisis of capitalism. In T. Biebricher \& F. Vogelmann (Eds.), The birth of austerity: German ordoliberalism and contemporary neoliberalism (pp. 51-72). London: Rowman \& Littlefield.

Hennecke, H. J. (2000). Friedrich August von Hayek: Die Tradition der Freiheit. Düsseldorf: Verlag Wirtschaft und Finanzen.

Hayek, F. A. (1934). Carl Menger. Economica, 1(4), 393-420.

Hayek, F. A. (1941). The pure theory of capital. Norwich: Jarrold \& Sons.

Hayek, F. A. (1944). The road to serfdom. Chicago: University of Chicago Press.

Hayek, F. A. (1960). The constitution of liberty. Chicago: University of Chicago Press.

Hill, L. E., Butler, C. E., \& Lorenzen, S. A. (1977). Inflation and the destruction of democracy: The case of the Weimar republic. Journal of Economic Issues, 11(2), 299-313.

Horn, K., \& Kolev, S. (2020). Dispute on method or dispute on institutional context? Foreword to the translation of Carl Menger's "Errors of Historicism". Econ Journal Watch, 17(2), 442-457.

Klausinger, H. (2005). Machlup, Morgenstern, Haberler, Hayek und andere: Wirtschaftspublizistische Beiträge in kritischer Zeit (1931-1934). Marburg: Metropolis.

Klausinger, H. (2006). From Mises to Morgenstern: Austrian economics during the Ständestaat. The Quarterly Journal of Austrian Economics, 9(3), 25-43.

Klausinger, H. (2014). Academic anti-semitism and the Austrian school: Vienna, 1918-1945. Atlantic Economic Journal, 42(2), 191-204.

Klausinger, H. (2015a). The Nationalökonomische Gesellschaft (Austrian economic association) in the interwar period and beyond. Research in the History of Economic Thought and Methodology, 34A, 9-43.

Klausinger, H. (2015b). Hans Mayer, last knight of the Austrian school, Vienna branch. History of Political Economy, 47(2), 241-305.

Kolev, S. (2019a). The puzzles of a triumvir: Friedrich von Wieser as political economist and sociologist. European Journal of the History of Economic Thought, 26(5), 942-972.

Kolev, S. (2019b). Warnruf an die Liberalen: Falsche Freunde Friedrich von Hayeks. Frankfurter Allgemeine Zeitung, 29 April 2019.

Kolev, S. (2020). Besieged by the left and the right: The order of liberal globalism. The Review of Austrian Economics, 33(4), 521-533.

Machlup, F. (1982). Austrian economics. In D. Greenwald (Ed.), Encyclopedia of economics (pp. 38-43). New York: McGraw-Hill.

Menger, C. (1871). Grundsätze der Volkswirthschaftslehre. Vienna: Wilhelm Braumüller.

Menger, C. (1883). Untersuchungen über die Methode der Socialwissenschaften, und der Politischen Oekonomie insbesondere. Leipzig: Duncker \& Humblot.

Mises, L. v. (1927 [2005]). Liberalism: The classical tradition. Indianapolis: Liberty Fund.

Olechowski, T. (2020). Hans Kelsen: Biographie eines Rechtswissenschaftlers. Tübingen: Mohr Siebeck. 
Perraton, J. (2007). Evaluating Marxian contributions to development economics. Journal of Economic Methodology, 14(1), 27-46.

Rüstow, A. (1932). Freie Wirtschaft - Starker Staat. In F. Boese (Ed.), Deutschland und die Weltkrise: Verhandlungen des Vereins für Socialpolitik in Dresden 1932 (pp. 62-69). Munich: Duncker \& Humblot.

Schmoller, G. (1873 [2004]). Review of Carl Menger's “Principles of Economics." In B. Caldwell, Hayek's challenge: An intellectual biography of F. A. Hayek (pp. 407-408). Chicago: University of Chicago Press.

Schumacher, R., \& Scheall, S. (2018). Karl Menger as son of Carl Menger. History of Political Economy, 50(4), 649-678.

Schumacher, R., \& Scheall, S. (2020). Karl Menger's unfinished biography of his father: New insights into Carl Menger's life through 1889. Research in the History of Economic Thought and Methodology, 38B, 155-189.

Schumpeter, J. A. (1939). Business cycles: A theoretical, historical, and statistical analysis of the capitalist process. New York: McGraw-Hill.

Schumpeter, J. A. (1942). Capitalism, socialism and democracy. New York: Harper \& Brothers.

Shackle, G. L. S. (1967). The years of high theory: Invention \& tradition in economic thought 1926-1939. Cambridge: Cambridge University Press.

Streissler, E. W. (1969). Structural economic thought: On the significance of the Austrian school today. Zeitschrift für Nationalökonomie, 29(3/4), 237-266.

Streissler, E. W. (1990). The influence of German economics on the work of Menger and Marshall. In B. Caldwell (Ed.), Carl Menger and his legacy in economics: Annual supplement to vol. 22, History of Political Economy (pp. 31-68). Durham: Duke University Press.

Streissler, E. W. (1999). "Arma virumque cano" - Friedrich von Wieser: der Sänger als Ökonom. In H. Hax (Ed.), Vademecum zu Friedrich von Wiesers "Über den Ursprung und die Hauptgesetze des wirtschaftlichen Werthes” (pp. 32-56). Düsseldorf: Verlag Wirtschaft und Finanzen.

Vanberg, V. J. (2011). Liberal constitutionalism, constitutional liberalism and democracy. Constitutional Political Economy, 22(1), 1-20.

Walter Eucken Institute (2020). Freiburg tradition: Friedrich A. von Hayek. https://www.eucken.de/en/ freiburg-tradition/friedrich-a-von-hayek/. Accessed 5 Sept 2020.

Wasserman, J. (2014). Black Vienna: The radical right in the red city, 1918-1938. Ithaca: Cornell University Press.

Wasserman, J. (2019). The marginal revolutionaries: How Austrian economists fought the war of ideas. New Haven: Yale University Press.

Wasserman, J. (2020). Science lost, science found in the post WWII Austrian economics movement: The case of Emil Kauder. The Review of Austrian Economics, 33(1/2), 107-120.

Weintraub, E. R. (Ed.). (2014). MIT and the transformation of American economics: Annual supplement to vol. 46, History of Political Economy. Durham: Duke University Press.

Wicker, E. (1986). Terminating hyperinflation in the dismembered Habsburg monarchy. The American Economic Review, 76(3), 350-364.

Wieser, F. v. (1891). The Austrian school and the theory of value. The Economic Journal, 1(1), 108-121.

Wieser, F. v. (1893). Natural value. London: Macmillan.

Yagi, K. (2011). Austrian and German economic thought: From subjectivism to social evolution. London: Routledge.

Publisher's note Springer Nature remains neutral with regard to jurisdictional claims in published maps and institutional affiliations. 